\title{
Profiling Readiness of Distance Education Using Technology in Senior High School during COVID-19 Pandemic
}

\author{
Neni Nurkhamidah ${ }^{1}$, Hormah Hidayatun Itsnaini², \\ ${ }^{1}$ STKIP Media Nusantara Citra, ${ }^{2}$ SMA N 1 Bandar \\ $\underline{\text { neni.nurkhamidah@stkipmnc.ac.id }}^{1}$, hormahhidayatun@gmail.com $^{2}$
}

Received: 24-09-2020 /Accepted: 25-12-2020 / Doi: https://doi.org/10.32923/sci.v5i1.1398

\begin{abstract}
ABSTRAK
Tujuan penelitian ini untuk mengetahui kesiapan SMA $\mathrm{N} 1$ Bandar dalam menyelenggarakan pendidikan jarak jauh dengan teknologi. Kesiapan diukur dengan menilai kesiapan siswa, guru dan institusi. Penelitian ini merupakan penelitian deskriptif yang melibatkan 220 (dua ratus dua puluh) siswa, 4 (empat) guru Bahasa Inggris, dan seorang Kepala Sekolah SMA N 1 Bandar. Kuesioner online dengan lima skala Likert digunakan untuk mengumpulkan data. Teknik analisis data dilakukan dengan skala penilaian yang terdiri dari empat kategori. Hasil keseluruhan menunjukkan skor kesiapan siswa 3,44 dan skor kesiapan guru 3,84. Keduanya menujukan bahwa mereka siap menerapkan pendidikan jarak jauh dengan teknologi. Skor kesiapan institusi adalah 3,21 yang menunjukkan bahwa institusi belum siap dan perlu perbaikan untuk penerapan pembelajaran jarak jauh dengan teknologi. Karena kesiapan adalah faktor krusial yang berperan penting dalam keberhasilan pembelajaran jarak jauh dengan teknologi, maka diperlukan penilaian kesiapan di setiap elemen di sekolah. Diharapkan sekolah dapat memanfaatkan hasil penelitian ini untuk meningkatkan kesiapan mereka dalam menempuh pendidikan jarak jauh selama pandemi COVID-19.
\end{abstract}

\section{Kata Kunci: Kesiapan siswa, kesiapan guru, kesiapan institusi , pembelajaran jarak jauh,}

\section{Introduction}

Covid-19 breakout at the beginning of 2020 brings various impacts to millions of people from almost all counties in the world. Economic, social, education, tourism, and industry sectors encounter significant consequences due to the virus. Store, hotel, and restaurant are closed, factories cannot carry out the production, and transportation limits the operation to prevent the higher spread of this pandemic. While the cases are getting an increase, people must keep their activities running. This situation triggers changing and shifting in many sectors as it happens also in Indonesian education. Because government restricts people to gather, many schools and universities can no more conduct face to face teaching and learning activities in the classroom.

In this paper, researchers use the term distance learning with technology to refers to online learning or e-learning. Those terms can be represented as learning without the limitation or constrain of time and place. It offers a student or a group of students flexible learning opportunities. Distance education is defined as an effort to provide an opportunity for teachers and students to teach and learn physically or geographically distant, at the same time or at different times. As new technology flourishes, the term distance learning grows to other learning types such as virtual learning, web-based learning, online learning, and e-Learning( Conrad ,2006) that form underlines those definitions on various instruction occurs between learners and instructor held at different times or places.

Various types of hardware, software, or application develop rapidly as the development of technology. The use of computers, laptops, mobile phones, the internet, social media, and digital games also highly expands in all aspects of humans' life including the educational field. From a huge number of educational technologies, Assar (2015) categories those types into three big groups: 
1) Standalone digital components are often called e-learning material, digital learning material, or digital learning objects. Video YouTube, pictures, and interactive assessment (online quizzes) belong to this category.

2) General communication and information tools are not designed for educational purposes, but they can support teaching and learning scenarios. This type including chat or voice, blogs, wiki, file sharing, and social networks.

3) Software to run online called as Learning Management System (LMS) or Course Management System (CMS). It is a complex and sophisticated online course activities software that provides content organization, material presentation, activities recording, activities tracking, activities management, chat, video communication, and assessment.

Many factors may affect the success of distance education with technology. Accuosti, J. (2014) point out the computer as an entity or tool, teachers as elements of facilitation, social environment, and teaching professional development as elements affecting online learning success. Other factors related to the success of the implementation of technology in e-learning are self-efficacy, compatibility, facilitating condition, training, and gender (Solangi, Al Shahrani, \& Pandhiani, 2018). Financial readiness level, infrastructure readiness condition, the availability of efficient technology, teacher and students attitude towards e-learning, and commitment in implementing online studies are founded as factor determine the success of e-learning Naveed et al (2020). Ten superior factors such as technical training, perception of usefulness, students' attitude toward e-learning, students' computer self-efficacy, quality of e-learning course, the flexibility of e-learning program, clarity of direction, content relevancy, and internet self-efficacy are founded by Xaymoungkhoun et al, 2012 as factors have a high influence on e-learning success. It is mentioned by Alberth (2011) that teacher and student characteristics, language skill characteristics, technology type, instructional design, supporting from institution to instructors and students are critical success factors in online learning. All those factors mentioned need to be considered in designing distance language by using technology because those factors potentially lead to the success of teaching and learning.

As teaching and learning during pandemics have to go on, distance learning with technology is suggested as an efficient way to keep running the class while the students staying at home. Most educational institutions in Indonesia are traditional based teaching and learning. Teaching and learning are conducted face-to-face in a classroom although blended learning has also been implemented. The different condition among schools in Indonesia makes the different level of readiness experienced. Many of those can easily perform distance learning by utilizing technology, on the other hand, some find obstacle in the implementation even cannot implement it because of unsupported factors.

Studies on e-learning readiness have been conducted by previous scholars in many contexts. In the COVID-19 pandemic, Alipio (2020) conducts research focusing on the students' readiness for e-learning in Philippine as a developed country. He involved 880 higher education students in Philippine. The result infers that the students are not ready for e-learning during the pandemic. Lack of equipment and internet connection plays a role in their readiness. Jaya, Hanafi, \& Febriana (2019) underline that public vocational schools in Jakarta are ready to conduct online learning. A study conducted by Waryanto \& Setyaningrum (2014) on 40 junior schools in Yogyakarta reveals that the score of school readiness in e-learning implementation is high. Several areas that have been assessed are readiness in sociological, technological skill, financial environmental, human resource, equipment, and content factors. Ramadiani et al (2020) in their study find out that teachers and students in three schools in Samarinda are ready to conduct online learning. Lo (2013) conducted a study in Banda Aceh and summaries that less than half of the schools in Banda Aceh are ready to implement e-learning although they face a variety of obstacles in financial, limited human resources, and lack of government supports. Pusparini, Santosa, \& Myartawan (2018) involved fivecomponent such as people, content, institution, technology, training, and acceptance as dimensions to measure English teachers' readiness in e-learning in Bali. The study reveals that English teachers in Singaraja public senior high schools are ready to implement e-learning but need few improvements.

This study is conducted in SMA N 1 Bandar, Batang Regency. This school is located in a rural area of Central Java. Since the pandemic happened, face to face teaching-learning shifted to distance learning by using Google Classroom, Google form, and Microsoft 365. Distance classroom is also supported by WhatsApp and zoom meeting. Since the national condition deal with Covid-19 is getting worse, distance learning has to be continued. In the implementation of distance learning using technology, there are many challenges faced because before the pandemic, online learning and e-learning is not common practice for the school. In this study, researchers try to find out students', teachers', and institution readiness in implementing distance education by using technology. As Success in distance learning using technology is significantly affected learning readiness Oliver (2001), this study is important to conduct. In this sense distance education with technology readiness must be conducted and reviewed carefully to improve education quality. By referring to the result of this study, hopefully, this study will be beneficial for students, teachers, and institutions to create effective and efficient distance learning with technology.

\section{Method of Research}

This descriptive study aims at finding students', teachers', and institution's readiness in the implementation of distance education using technology. It involves 220 (two hundred and twenty) students, 4 (four) English teachers, and a principle of SMA N 1 Bandar. Primary data are collected by using a questionnaire in form of an online questionnaire with a five-point Likert scale. The scale of Likert is one to five ranged from strongly disagree to 
strongly agree. Questionnaire items are composed based on the most common dimension model of e-learning readiness analyzed by Demir, Ömer \& Yurdugül, Halil. (2015). Twenty questionnaires item of students' readiness dimension is divided into some area. Competency of technology usage (Forson \& Vuopala, 2019), self-directed (Forson \& Vuopala, 2019 and Mustafa \& Raside, 2016), supporting technology (Pusparini, Santosa, \& Myartawan, 2018), self-confidence in prerequisite skills (Ünal, Alır, \& Soydal,2013), motivation (Kayaoğlu \& Akbaş, 2016) and time management (Tuntirojanawong, 2013). Twenty questionnaire items are also provided for the teacher. The items include technology competency (Matanaghi, 2015), access to technology (Pusparini, Santosa, \& Myartawan, 2018), acceptance (Pusparini, Santosa, \& Myartawan, 2018), pedagogical (Al-Awidi \& Aldhafeeri, 2017), and time management (Ventayen, 2018). The last measurement is institutional readiness. In this matter, the principle school as the head of the institution responds to ten questionnaires items related to ICT infrastructure Mulwa \& Kyalo (2011), financial and human resources (Mercado 2008) as the measurement element. To determine the level of readiness, researchers use an assessment introduced by Aydin and Tasci (2005).

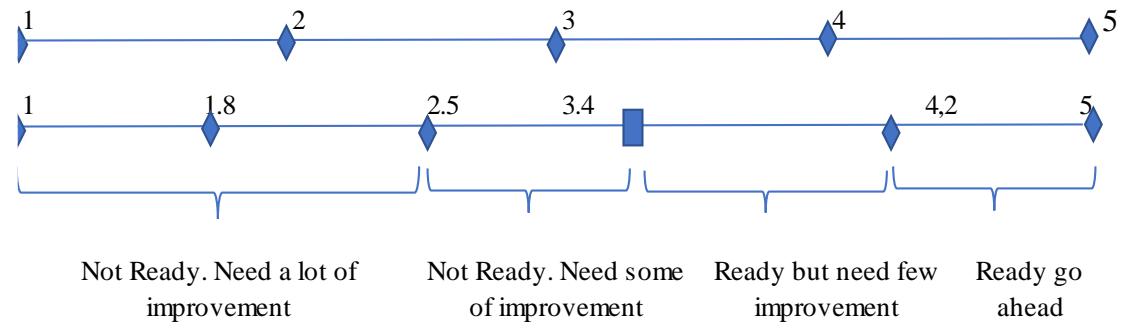

Figure 1.

E-learning Assessment by Aydin \& Tasci (2005)

\section{Result}

In this part researchers show analysis of given questionnaire to students, teacher, and the principle of SMA N 1 Bandar.

Table 1. Result of Profiling Readiness on Distance Learning with Technology.

\begin{tabular}{lll}
\hline Subject Being Assess & Score & Category \\
\hline Students & 3.44 & Ready but still needs a few improvements \\
Teachers & 3.84 & Ready but still needs a few improvements \\
Institution & 3.21 & Not ready and need some improvement
\end{tabular}

Overall students' readiness is 3.44 and teachers' readiness is 3.84 indicating they are ready for distance education by using technology but still need few improvements. The institution readiness score is 3.21 indicating that the institution is not ready for distance education with technology. The description of every students', teachers' and institutional readiness will be discussed in the following part.

\section{Discussion}

\subsection{Students Readiness in Distance Learning Using Technology}

\subsubsection{Competency of technology usage}

This competence refers to the basic ability of students to operate technological devices such as computers and mobile phones, email, social media, and the internet. Technology competence is very crucial to be mastered by students since it has a positive impact on students' motivation in online learning (Harrandi, 2015). Muilenburg, \& Berge (2005) reveal that students with a high level of comfort and confidence in using technologies perceived few barriers for social interaction in learning, administrative issues, learner motivation, and time and support for studies. This situation will trigger students to be more engaged in the learning process. Technological competence also influences the success of their online learning because students with a good technology competency are found to have moderate competency in interaction with learning content, (Sadita, Santoso, Soeradijono, \& Suhartanto, 2017). Students' technology competence of SMA N 1 Bandar is categorized high. Score 3.62 indicates that they are ready for distance learning with technology.

\subsubsection{Self-directed}


Self-directed learning is defined as learner's ability to learn independently. Self-directed relates to students'

learning outcomes (Cazan,\& Schiopca, 2014) and assumed as a significant factor in the success of distance learning (Lasfeto, 2020). Distance learning with technology demands students to initiate, explore, and generate knowledge (Garrison, 2005). Here self-directed is needed because it enables students to adopt the right behaviors, have a responsibility, and manage themselves in the learning process. Result of questionnaires shows that the level students' self-directed learning related to their ability to set learning goals, focus on course and assignment, keep their motivation, changing plan and seek assistance is needed is 3.43. This score refers that they are ready for distance learning with technology.

\subsubsection{Supporting Technology}

In the questionnaire, researchers ask students about availability to access either computer or mobile phone with an internet connection used during distance learning. The result shows a score of supporting technology readiness is 3.39 indicating that students are not ready to conduct distance learning from a supporting technology point of view. Even though they have a computer and mobile phone, they will face the problem the internet connection is not available. The lack of internet connection caused by location is not covered with an Internet provider or financial support to buy internet data. Many researchers find that the lack of technological support is the main barrier in implementing technology in English language teaching and learning ( O’Doherty et all,2018; Elzawi \& Wade, 2012; Al-Azawei, Parslow \& Lundqvist,2016; Taurus et al,2015). Since technological support play important role in distance learning, this factor must be stressed to achieve the success of students' learning.

\subsubsection{Self Confidence in Prerequisite Skills}

Self-confidence is a type of belief that manifests itself from people's subjective observations of their knowledge. The lack of confidence might hinder students in learning. Students with high confidence are more likely to well perform in online learning (Swan, 2004). The result of the questionnaire shows that students' self-confidence in distance learning is 3.14. This is the lowest score among other factors of students' readiness. The teacher may help students to increase their motivation by providing online interaction (Wu, Yen \& Marek,2011). In larger circumstance school also may provide training about the use of online learning platforms, therefore students will be familiar and comfortable to use it in distance learning.

\subsubsection{Motivation}

In many types of learning environment, motivation is considered as the primary factor that affects students' success (Schunk \& Usher, 2012), since it influences what learners learn, how they learn, and when they choose to learn. Motivation is recognized as one of the high-level factor that influences students' persistence in their academic tasks (Hart, 2012), engagement (Shapiro et al., 2017), self-regulated learning (Magen-Nagar \& Cohen, 2017) and facilitate their efforts to get higher achievement including grades, awards, or prizes (Baeten, et al. 2010). A huge number of studies about motivation in online or e-learning have been conducted in a different environment but not in force majeure condition as experienced by learners all over the world in the COVID-19 pandemic. Among all elements of students' readiness, motivation is found as the highest score. The result shows that the motivation score of student's readiness is 3.66. It concludes that students have high motivation to lead and support them joining distance learning using technology.

\subsubsection{Time management}

Time management is the last element used to assess student's readiness for distance learning using technology. In this context, researchers refer to time management as teachers' ability to set personal habits on how to manage time effectively and manage maximum activities in a given time. Different habits will influence time consumption and time management (Foltynek and Motycka 2009). Therefore, students have to practice efficient habits to support their learning in distance. The crucial of time management in learning online learning and e-learning has been revealed by Whipp et al.( 2001) that mentions if the ability to manage time is predictive of learning achievement. The result of the readiness assessment of students in SMA N 1 Bandar related to the time management element is high. With a score of 3.41 points that they are ready for distance learning.

\subsection{Teachers' Readiness in Distance Teaching Using Technology}

\subsubsection{Technology competency}

The ability to use technology is demanded competence for a teacher in future education (Clark,2019 and Huda et all, 2016). Many frameworks have released profiling and framework of teacher technological competence for language teaching. UNESCO (2018) in UNESCO ICT Competency Framework explains that teachers have to be able to use computers, mobile devices, accessible software, and networks. This framework also describes more detail about enabling competence for the teachers such as navigating the internet, using a search engine, using email, and creating a presentation. The skill mentioned in the framework is a basic skill that must be equipped by the teacher for teaching. Readiness assessment on teachers' technological competence shows that with the ability in performing the basic function of Microsoft office, teaching software, and the internet, they are ready to implement distance teaching with technology. But a score of 4.16 indicates that teachers still need little improvement for conducting teaching with technology

\subsubsection{Access to technology}

Lack of supporting technology in distance teaching may cause the problem and hinder the success of teaching To 
assess teachers' readiness in accessing technology, researchers dig their availability of a dependable computer, portable computer, and mobile phone for teaching. The availability of Internet connection is also being assessed to make sure that they are supported by proper connection. Not only the availability of infrastructure, but researchers also analyze teacher's ability to access the course. The result of teacher's readiness in accessing technology is 3.91. The results point out that they are ready to conduct distance teaching with few improvements.

\subsubsection{Acceptance}

This element tries to figure out how teachers perceive the usefulness and easiness of e-learning and online learning of distance learning using technology in English teaching-learning. Successful implementation of online teaching relies on teachers' attitudes(Teo, Ursavaş,\& Bahçekapili, 2012). Therefore, teachers have to have a positive perception and attitude toward it. In this part, teachers are demanded to answer questions related to the effectiveness of learning with technology, easiness of learning with technology implementation and learning with technology support education quality. English teachers' acceptance of learning with technology shows a score of 3,75 referring that they accept the existence and advantage of distance teaching with technology.

\subsubsection{Pedagogical}

Pedagogical readiness figures out the suitability between technology and educational practice especially in teaching and learning activities (Bappa-Aliyu, 2012). With the diversity of background knowledge and skills to utilize technology in education, the teacher may have different readiness in integrating technology in the teaching and learning process. Some teacher may be ready with their pedagogical level, some may feel inconvenience to shift all face to face activities to online learning. As it is shown in the result of the questionnaire, the score of teacher readiness in the pedagogical element is 3.75 indicates they are ready but need little improvement. It is suggested that schools provide training to strengthen teachers' pedagogical aspect. Therefore, effective teaching with technology can be successfully conducted,

\subsubsection{Time management}

Time management problem does not only happen to students in distance learning, the teacher may also experience this matter in distance teaching. (Huda et all, 2017) points out that some teaching competencies should be engaged in the digital era. Those competencies include time management, planning commitment, and technology skills. Related to time management, what successful e-learning need are teachers' self-discipline and teachers' commitment to obey the deadlines. Teachers' time management in distance learning with technology shows a score of 3,79 indicates that they still need little improvement on their time management. Some tips that can be followed by teachers to help them manage their time are setting up a goal, time table, and clear to-do list. They also need to commit to doing activities as they write on their plan.

\subsection{Institutional Readiness in Distance Learning Using Technology}

The last assessment readiness in this study is the school's readiness as an institution that carries out and organizes the program to support teaching and learning. In this study, researchers use two elements to assess school readiness in distance learning. First is the availability of ICT infrastructure and the second is the availability of financial and human resources to support distance education. Indonesian 2013 Curriculum emphasizing the integration of Information and Communication Technology (ICT) in teaching and learning. But in fact, there are still many problems faced by the school to implement technology in education including SMA N 1 Bandar. The result of the questionnaire shows that school is not ready to conduct distance learning in the matter of supporting ICT infrastructure, financial and human resources.

\subsubsection{ICT infrastructure}

Many studies reveal that schools in Indonesia face problems in implementing technology in education because of a lack of ICT infrastructure (Hermawan \& Yunita, 2018; Febriana, Nurkamto, Rochsantiningsih, and Muhtia, 2018; Maulida, \& Lo, 2013; Kusumo, Kurniawan, \& Putri;2012). Unavailability of computer, electricity, and internet connection causes education with technology cannot be conducted. The result of the questionnaire shows that SMA N 1 Bandar is not ready to conduct distance learning with technology. The score of ICT infrastructure readiness is 3,33 referring lack of sufficient equipment, sufficient energy source, and proper internet connection

\subsubsection{Financial and Human Resources}

This element explores budget availability to support distance learning with technology. Since the COVID-19 pandemic is an unpredictable case that forces the educational field to keep running, learning with technology in distance is the possible and profitable option. The sudden implementation of E-learning and online learning may be conducted with an unprepared budget. On the other hand, the ability of the institution to afford equipment and maintain infrastructure is affected by the financial condition. If there is no sufficient budget, it is hard for the school to fulfill its ICT infrastructure need. Human resources will also affect the success of distance learning implementation. Human resources in this study related to the availability of human to support online and e-learning system. Human resources refer to IT employee, policy maker on distance learning, and qualified supervisor teacher that make sure the success of learning. In this study, researchers found that SMA N 1 Bandar is not ready to conduct distance learning with technology from financial and human resources areas. The readiness score is 3.21. Government and school policies impact financial and human resources readiness. Therefore, a school in this case the principal has to determine profitable policies related 
to financial and human resources matters to support distance learning with technology.

\section{Conclusion}

This descriptive study shows that students, teachers, and institutions have different profiling levels of readiness to conduct distance learning with technology during the COVID-19 pandemic. The result of the overall online questionnaire shows students' readiness score is 3,44 and teachers readiness score is 3.84 indicates they are ready but still need little improvement. On the other hand, the institution readiness score is 3.21 indicating that the institution is not ready and needs some improvement to get it ready for distance learning with technology. The detailed analysis reveals that students are ready with their competency of technology usage, self-directed, motivation, and time management. Supporting technology and students' self-confidence in prerequisite skills are two areas with the lowest score and need many improvements. Teachers' readiness shows that they are ready to teach with technology in the distance even though they still need few improvements. Readiness is shown from teachers' technology competency, the ability, and availability to access technology, teachers' acceptance of technology in distance learning, teachers' pedagogical and time management. From institution readiness, the result shows a low score of financial and human resources readiness indicating the institution is not ready to establish distance education with technology.

It is important to assess readiness for distance learning with technology during the COVID-19 pandemic to make sure that every element is ready. By referring to the result of this study, SMAN 1 Bandar can improve and fix students, teachers, and institutional readiness in conducting distance education with technology. Since there are many challenges faced in the implementation of distance learning, establish corporation with the government, private institutions and other schools will be beneficial for the school. Supporting the form of technology infrastructure and training

\section{References}

Accuosti, J. (2014), "Factors affecting education technology success", ASEE 2014 Zone I Conference, April 3-5, available at: www.asee.org/documents/zones/zone1/2014/ Student/PDFs/112.pdf

Al-Awidi, H., \& Aldhafeeri, F. (2017). Teachers'readiness To Implement Digital Curriculum In Kuwaiti Schools. Journal of Information Technology Education, 16(1).

Al-Azawei, A., Parslow, P., \& Lundqvist, K. (2016). Barriers and opportunities of e-learning implementation in Iraq: A case of public universities. The International Review of Research in Open and Distributed Learning, 17(5).

Alberth, A. (2011). Critical success factors in online language learning. TEFLIN journal, 22(1), 16-33.

Alipio, M. (2020). Education during COVID-19 era: Are learners in a less-economically developed country ready for elearning?. Available at SSRN 3586311.

Ally, M. (2019). Competency profile of the digital and online teacher in future education. International Review of Research in Open and Distributed Learning, 20(2).

Assar, S. (2015). Information and Communication Technology in Education. International Encyclopedia of the Social \& Behavioral Sciences (Second Edition), 66-71. doi:https://doi.org/10.1016/B978-0-08-097086- 8.92104-4

Aydin, Cengiz \& Tasci, Deniz. (2005). Measuring Readiness for e-Learning: Reflections from an Emerging Country. Educational Technology \& Society. 8. 244-257.

Bappa-Aliyu, M. (2012, June). Challenges and Barriers to Successful Integration of Information and Communication Technologies (ICTs) in Nigeria. Journal of Technical, Vocational \& Engineering Education, 6, 124-130.

Baeten, M., Kyndt, E., Struyven, K. \& Dochy, F. (2010). Using Student-Centered Learning Environments to Stimulate Deep Approaches to Learning: Factors Encouraging Or Discouraging Their Effectiveness. Educational Research Review, 5(3), 243-260.

Cazan, A. M., \& Schiopca, B. A. (2014). Self-directed learning, personality traits and academic achievement. ProcediaSocial and Behavioral Sciences, 127, 640-644.

Clark, R. (2002). Six principles of effective e-Learning: What works and why. The eLearning Developer's Journal, 1-10

Conrad, D. (2006). E-Learning and Social Change: An apparent contradiction. In In. M. Beaudoin (Ed.), Perspectives on higher education in the digital age. New York: Nova Science Publishers.

Demir, Ömer \& Yurdugül, Halil. (2015). The Exploration of Models Regarding E-learning Readiness: Reference Model Suggestions. International Journal of Progressive Education. 11. 173-194.

Elzawi, A., \& Wade, S. (2012). Barriers to ICT adoption in quality of engineering research in Libya: how to bridge the digital divide?. University of Huddersfield.

Febriana, M., Nurkamto, J., Rochsantiningsih, D. and Muhtia, A. (2018) "RETRACTED: Teaching in Rural Indonesian Schools: Teachers' Challenges", International Journal of Language Teaching and Education, 2(2), pp. 87-96

Foltynek, T., \& Motycka, A. (2008). Time Management in E-learning. Faculty of business and Economics, department of Informatics, Mendel University, Czech Republic, 112-130.

Forson, I. K., \& Vuopala, E. (2019). Online Learning Readiness: Perspective of Students Enrolled in Distance Education In Ghana. The Online Journal of Distance Education and e-Learning, 7(4), 277.

Garrison, D. R., \& Cleveland-Innes, M. (2005). Facilitating cognitive presence in online learning: Interaction is not enough. American Journal of Distance Education, 19(3), 133-14 
Rajaee Harandi, Safiyeh. (2015). Effects of e-learning on Students' Motivation. Procedia - Social and Behavioral Sciences. 181. 10.1016/j.sbspro.2015.04.905.

Hart, C. (2012). Factors associated with student persistence in an online program of study: A review of the literature. Journal of Interactive Online Learning, 11(1).

Hermawan, H. D., Deswila, N., \& Yunita, D. N. (2018). Implementation of ICT in Education in Indonesia During 20042017. International Symposium on Educational Technology (ISET) (pp. 108-112). IEEE.

Huda, M., Anshari, M., Almunawar, M. N., Shahrill, M., Tan, A., Jaidin, J. H., \& Masri, M. (2016). Innovative Teaching in Higher Education: The Big Data Approach. The Turkish Online Journal of Educational Technology, 15(Special issue), 1210-1216

Huda, M., Maseleno, A., Shahrill, M., Jasmi, K. A., Mustari, I., \& Basiron, B. (2017). Exploring adaptive teaching competencies in big data era. International Journal of Emerging Technologies in Learning (iJET), 12(03), 68-83.

Jaya, A., Hanafi, I. and Febriana, R. 2019. E-Learning Readiness Measurement in SMK Negeri DKI Jakarta. KnE Social Sciences. 3, 12 (Mar. 2019), 507-515. DOI:https://doi.org/10.18502/kss.v3i12.4119.

Kayaoğlu, M \& Dağ Akbaş,. (2016). Online Learning Readiness: A Case Study in the Field of English for Medical Purposes. Participatory Educational Research (PER). Special Issue 2016-IV. 212-220.

N. S. A. M. Kusumo, F. B. Kurniawan, and N. I. Putri, "eLearning Obstacle Faced by Indonesian Students, " Special Issue of the International Journal of the Computer, the Internet, and Management, vol. 19 No. SP2, no. February, pp. 1$4,2012$.

Lasfeto, D. (2020). The Relationship Between Self-Directed Learning and Students' Social Interaction In Online Learning Environment. Journal of e-Learning and Knowledge Society, 16(2), 34-41.

Lo,JJ (2013). E-learning readiness in senior high school in Banda Aceh, Indonesia. Journal of Information Technology and Applications (資訊科技與應用期刊), 7(4), 122-132.

Magen-Nagar, N., \& Cohen, L. (2017). Learning strategies as a mediator for motivation and a sense of achievement among students who study in MOOCs. Education and Information Technologies, 22(3), 1271-1290.

Matanaghi, A. (2015). Online Learning Readiness Level and Perceived Social Presence of The Teacher Candidate's in The Online Learning Environment an EMU Example (Master's thesis, Eastern Mediterranean University (EMU)-

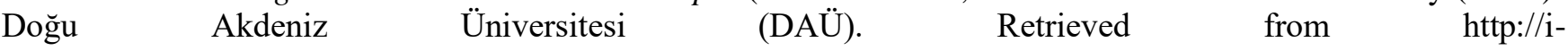
rep.emu.edu.tr:8080/jspui/bitstream/11129/3193/1/matanaylar.pdf

Maulida, I. F., \& Lo, J. (2013). E-learning Readiness in Senior High Schools in Banda Aceh, Indonesia. Information Technology and Applications, 7(4), 122-132.

Mercado, C. (2008). Readiness assessment tool for an e-learning environment implementation. Special Issue of the International Journal of the Computer, the Internet and Management, 16, 18-11.

Muilenburg, Lin \& Berge, Zane. (2001). Barriers to Distance Education: A Factor-Analytic Study. American Journal of Distance Education. 15. 7-22. 10.1080/08923640109527081.

Mulwa, A., Kyalo, N., Bowa, O., \& Mboroki, G (2011). The influence of ICT infrastructure on readiness to adopt elearning in secondary schools in Kitui district, Kenya. Journal of Continuing Open and Distance Education, 23.

Naveed et al (2020). Evaluating critical success factors in implementing E-learning system using multi-criteria decisionmaking. PLOS ONE, 15(5), 1-25.

Oliver, R. G. (2001). Assuring the quality of online learning in Australian higher education. Proceedings of 2000 Moving Online Conference (pp. 222-231). Gold Coast, QLD. Norsearch Reprographics

O’Doherty, D., Dromey, M., Lougheed, J., Hannigan, A., Last, J., \& McGrath, D. (2018). Barriers and solutions to online learning in medical education-an integrative review. BMC medical education, 18(1), 130.

Pusparini, Santosa, \& Myartawan, (2018). An Investigation on Teachers' E-learning Readiness toward E-learning Implementation in Public Senior High Schools in Singaraja, Bali, Indonesia. Jurnal Pendidikan Bahasa Inggris undiksha, 5(2).

Ramadiani, Ramadiani \& Azainil, Azainil \& Hidayanto, Achmad \& Jundillah, Muhammad \& Khairina, Dyna. (2020). Teacher and student readiness using e-Learning and m-Learning in Samarinda. Bulletin of Electrical Engineering and Informatics. Vol.9. 10.11591/eei.v9i3.2006.

Sadita, L., Santoso, H. B., Soeradijono, S. H., \& Suhartanto, H. (2017). Assessing students'e-learning competencies in online learning environment. International Conference on Advanced Computer Science and Information Systems (ICACSIS) (pp. 489-494). IEEE.

Shapiro, H. B., Lee, C. H., Roth, N. E. W., Li, K., Çetinkaya-Rundel, M., \& Canelas, D. A. (2017). Understanding the massive open online course (MOOC) student experience: An examination of attitudes, motivations, and barriers. Computers \& Education, 110, 35-50.

Solangi, Z. A., Al Shahrani, F., \& Pandhiani, S. M. (2018). Factors affecting successful implementation of eLearning: Study of colleges and institutes sector RCJ Saudi Arabia. International Journal of Emerging Technologies in Learning (iJET), 13(06), 223-230.

Schunk, D. H., \& Usher, E. L. (2012). Social cognitive theory and motivation. In R. M. Ryan (Ed.), Oxford library of 
psychology. The Oxford handbook of human motivation (p. 13-27). Oxford University Press.

Swan, K. (2004). Learning online: a review of current research on issues of interface, teaching presence and learner characteristics. Paper presented at the Elements of Quality Online Education, Needham, MA.

Teo, T., Ursavaş, Ö. F., \& Bahçekapili, E. (2012). An assessment of pre-service teachers' technology acceptance in Turkey: A structural equation modeling approach. Asia-Pacific Education Researcher, 21(1), 191-202.

Tuntirojanawong, S. (2013). Students' Readiness for E-Learning: A Case Study of Sukhothai Thammathirat Open University, Thailand. Journal of Learning in Higher Education, 9(1), 59-66.

Ünal, Y., Alır, G., \& Soydal, İ. (2013). Students readiness for e-learning: an assessment on Hacettepe University Department of Information Management. International Symposium on Information Management in a Changing World (pp. 137-147).

UNESCO (2018) UNESCO ICT Competency Framework for Teachers. Paris: UNESCO.

Ventayen, R. J. M. (2018). Teachers' Readiness in Online Teaching Environment: A Case of Department of Education Teachers. PSU Journal of Education, Management and Social Sciences, 2(1).

Waryanto, N.H., \& Setyaningrum, W. (2014). E-Learning Readiness in Indonesia: A Case Study in Junior High School Yogyakarta. Proceedings of the International Seminar on Innovation in Mathematics and Mathematics Education 2014 (pp. 645-654). Yogyakarta, Indonesia.

Whipp, J. L., and Chiarelli, S. (2001). Proposal: Self-regulation in web-based courses for teachers. Submitted to: Division K:Section1d: Teaching, Teacher Education with and for Students and Teacher Learning in Technology. http://edtech.connect.msu.edu/Searchaera2002/viewproposaltext.asp?propID=1696, Date Accessed: 24/04/06

Wu, W. C. V., Yen, L. L., \& Marek, M. (2011). Using online EFL interaction to increase confidence, motivation, and ability. Journal of Educational Technology \& Society, 14(3), 118-129.

Xaymoungkhoun, O., Bhuasiri, W., Rho, J. J., ZO, H., \& Kim, M. (2012). The critical success factors of e-learning in developing countries. Kasetsart Journal-Social Sciences, 33(2), 321-332 